\title{
Heparin: role in protein purification and substitution with animal-component free material
}

\author{
Svenja Nicolin Bolten ${ }^{1}$. Ursula Rinas ${ }^{1,2} \cdot$ Thomas Scheper $^{1}$
}

Received: 12 April 2018 / Revised: 20 July 2018 / Accepted: 21 July 2018 / Published online: 9 August 2018

(C) The Author(s) 2018

\begin{abstract}
Heparin is a highly sulfated polysaccharide which belongs to the family of glycosaminoglycans. It is involved in various important biological activities. The major biological purpose is the inhibition of the coagulation cascade to maintain the blood flow in the vasculature. These properties are employed in several therapeutic drugs. Heparin's activities are associated with its interaction to various proteins. To date, the structural heparin-protein interactions are not completely understood. This review gives a general overview of specific patterns and functional groups which are involved in the heparin-protein binding. An understanding of the heparin-protein interactions at the molecular level is not only advantageous in the therapeutic application but also in biotechnological application of heparin for downstreaming. This review focuses on the heparin affinity chromatography. Diverse recombinant proteins can be successfully purified by this method. While effective, it is disadvantageous that heparin is an animal-derived material. Animal-based components carry the risk of contamination. Therefore, they are liable to strict quality controls and the validation of effective good manufacturing practice (GMP) implementation. Hence, adequate alternatives to animal-derived components are needed. This review examines strategies to avoid these disadvantages. Thereby, alternatives for the provision of heparin such as chemical synthesized heparin, chemoenzymatic heparin, and bioengineered heparin are discussed. Moreover, the usage of other chromatographic systems mimetic the heparin effect is reviewed.
\end{abstract}

Keywords Heparin - Heparin-binding proteins · Heparin-protein interactions · Heparin affinity chromatography . Animal-component free

\section{Introduction}

The discovery of heparin took place in 1916 when Jay McLean and William Howell isolated a glycosaminoglycan from liver tissues that inhibited blood coagulation. It was called heparin (Greek hepar-liver) (McLean 1959; Marcum 1997). In 1928, Howell identified uronic acid as one sugar component in heparin. Seven years later in 1935, Bergstrom

Electronic supplementary material The online version of this article (https://doi.org/10.1007/s00253-018-9263-3) contains supplementary material, which is available to authorized users.

Thomas Scheper

scheper@iftc.uni-hannover.de

1 Institute of Technical Chemistry, Leibniz University of Hannover, Callinstraße 5, 30167 Hannover, Germany

2 Helmholtz Centre for Infection Research, Inhoffenstraße 7, 38124 Braunschweig, Germany and Jorpes discovered glucosamine $(\mathrm{GlcN})$ as the second sugar component in heparin (Jorpes and Bergström 1936). Jorpes determined in 1936 that heparin contains a high amount of sulfo groups which makes heparin one of the strongest known acids. Furthermore, he found out that the sulfo groups are located at the N-residue of GlcN. Several research groups expanded the isolation of heparin first from bovine lung and later from porcine intestine (Liu et al. 2009). At the same time, Jorpes in collaboration with Charles and Scott prepared heparin with acceptable purity for human trials. In 1959, Crafoord and Best showed that heparin treatment prevents postoperative thrombosis. Nevertheless, studies at the Mayo Clinic, Minnesota, revealed that heparin causes side effects such as headaches, fever, nausea, or heparin-induced thrombocytopenia (HIT) (Best 1959). To avoid these side effects, a lowmolecular-weight (LMW) heparin fraction was isolated. LMW heparin features defined biological and chemical properties. It shows the desired pharmacological effect, a better bioavailability, a higher therapeutic index, and fewer side effects. Since the 1970s LMW heparin is used for surgery 
patients to avoid uncontrolled thrombosis (Linhardt and Gunay 1999).

Additionally, since the 1970s heparin is also used in biotechnological processes. It is required as supplement in cell culture media. Furthermore, heparin is used as a specific ligand in affinity chromatography systems to purify protein mixtures due to its interactions with a variety of proteins (Olivecrona et al. 1971; Nordenman and Björk 1977; Shelburne et al. 1977). Nevertheless, heparin is an animalderived product. Animal products carry the risk of adulterations and contaminations. Based on this risks and the expensive preparation of heparin, a replacement of heparin is of enormous interest in pharmaceutical and biotechnological processes. Hence, this review covers the properties and structure of heparin and the heparin-protein interactions. Strategies for the replacement of heparin in affinity chromatography are also described.

\section{Structure of heparin}

Heparin is part of the family of glycosaminoglycans (GAGs), which are linear polysaccharides characterized by repeating disaccharide units (Perlin and Mazurek 1968; Esko and Linhardt 2009). These repeating units are $1 \rightarrow 4$ glycosidic linked uronic acid and glucosamine residues (Best 1959). Heparin consists of $75-95 \%$ of a trisulfated disaccharide repeating unit, $2-O$-sulfo- $\alpha$-L-iduronic acid $1 \rightarrow 4$ linked to 6O-sulfo- $N$-sulfo- $\alpha$-D-glucosamine $(\rightarrow 4]$ IdoA- $\left(2 \mathrm{SO}_{3}\right)-(1 \rightarrow$ 4)-GlcNS-(6SO $)_{3}$-[1 $\rightarrow$ ) (Fig. 1) (Liu et al. 2009).

Nevertheless, there are also structural variations of this disaccharide causing variable heparin sequences. The reason for these variations is that uronic acid consists of L-iduronic acid and Dglucuronic acid, which further can be substituted with a 2-Osulfo group. Furthermore, the glucosamine can also be substituted. Thereby, the amino group can be unsubstituted or substituted with a sulfo or acetyl group. Furthermore, the hydroxyl group on position 3 and 6 can also be substituted with an $O$-sulfo group or still be unsubstituted (Handel et al. 2005). The molecular weight of heparin is in the range of 5 and $40 \mathrm{kDa}$ due to its polydisperse mixture (Handel et al. 2005).

\section{Biological function of heparin}

Heparin is a linear molecule with a helical order which is located intracellularly in mast cells and basophil granules (Mulloy et al. 1993). Its major biological function is the inhibition of the coagulation cascade to maintain the blood flow in the vasculature (Hileman et al. 1998).

It is assumed that L-iduronic acid residues are flexible and responsible for a specific orientation of $O$ - and $S$-groups which allows heparin to bind diverse biologically important proteins (Mulloy and Linhardt 2001) such as cytokines, morphogens, growth factors, chemokines, and adhesion molecules (Gandhi and Mancera 2008). Heparin interacts with these heparin-binding proteins via ionic or hydrogen bonds between heparin's sulfo groups and the amino groups of the protein. Heparin is further involved in different biological processes as cell differentiation, cell growth and migration, inflammation, and pathogen infection (Hileman et al. 1998).

\section{Provision of heparin}

Heparin is a natural product isolated mainly from porcine or bovine tissues. Since the 90 s, pharmaceutical heparin is only isolated from porcine intestines because of the bovine spongiform encephalopathy (BSE) crisis. The composition of heparin in the intestines differs. The whole intestine or just the mucosa can be taken for the extraction of heparin. Furthermore, different subspecies of pigs, the habitat, and diet of the pigs have an influence on the composition of heparin (Liu et al. 2009). These factors enhance the already complex composition of heparin. The extraction of pharmaceuticalgrade heparin is subject to industrial confidentiality. There are some patents and publications explaining generally used pharmaceutical processes. It starts with the preparation of the tissues and the adjoining extraction of heparin from those. Both steps are at the slaughterhouse and are not subject of current good manufacturing practice (cGMP) conditions. It follows the recovery and purification of raw heparin which are liable under cGMP conditions and can handle with
Fig. 1 Repeating units of the major and minor disaccharides in heparin. a 2-O-sulfo- $\alpha$-L-iduronic acid. b 6-O-sulfo- $N$-sulfo- $\alpha$-Dglucosamine. c Structural variations of the disaccharide (X $=\mathrm{H}_{\text {or }} \mathrm{SO}_{3}{ }^{-}, \mathrm{Y}=\mathrm{Ac}, \mathrm{SO}_{3}{ }^{-}$, or $\mathrm{H})$. Scheme was adapted from (Capila and Linhardt 2002)

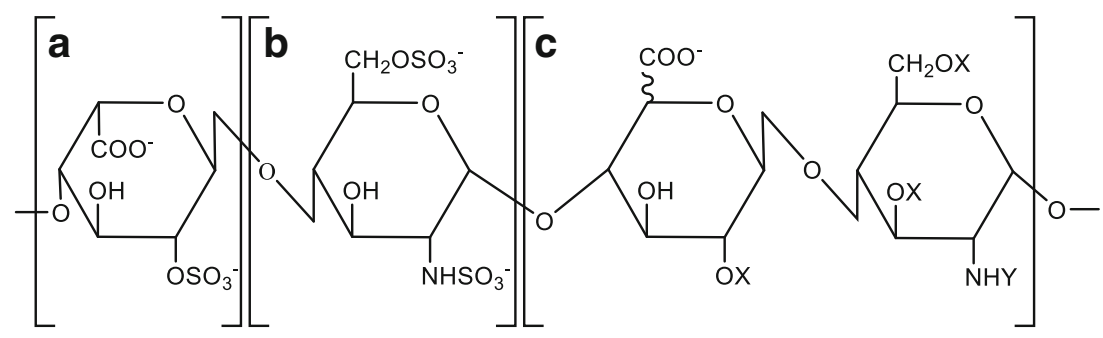

major sequence variable sequence 
impurities such as other GAGs, heavy metals, bacterial endotoxins, viruses, and bioburden (Liu et al. 2009; Volpi et al. 2012).

\section{Options of applications of heparin}

Heparin is widely used as a therapeutic agent due to its anticoagulation effects to avoid thrombosis. Furthermore, it is injected intravenously to patients during extracorporeal procedures for example during hemodialyses and membrane oxygenation in chirurgic cardiac surgery (Langer et al. 1982).

Besides these extremely important medical applications, heparin is also used in biotechnological research. For example, heparin is used on microarrays for high-throughput analysis of heparin-protein interactions. This process is used for the development of new drugs in antithrombotic use (Park et al. 2008).

Due to Heparin's specific interactions with various proteins, it is also utilized for protein purification processes (Staby et al. 2005). In this case, heparin is covalently immobilized on a porous bead and acts as a specific affinity ligand. On the basis of its high amount of anionic sulphate groups, it functions also as a cation exchanger (Xiong et al. 2008; Guan and Chen 2014). Protein mixtures can be separated using heparin affinity chromatography columns. Furthermore, the application of heparin affinity chromatography columns often results in concentration of heparin-binding proteins from cell lysates even if they are only present in low concentration (Xiong et al. 2008).

\section{Advantages and disadvantages of heparin affinity chromatography}

The heparin-binding domain of proteins is very important for their biological function. Therefore, the domain is easily accessible for heparin and this takes an advantage in the purification process of recombinant proteins. The heparin affinity chromatography is a very effective and simple method to purify a wide range of proteins. It has a high purification potential and is also easy to handle (Farooqui 1980; Staby et al. 2005; Xiong et al. 2008; Guan and Chen 2014). The heparin affinity chromatography is not dependent on an affinity-tag in contrast to other affinity chromatography systems such as immobilized-metal affinity chromatography (IMAC). Heparin affinity chromatography columns are compatible with oxidizing and reducing agents and chelators (e.g., EDTA) (Farooqui 1980; Xiong et al. 2008).

In the literature, several hundreds of glycosaminoglycanbinding proteins (Table 1) are found (Ori et al. 2011). Different classes of proteins such as the growth factors basic fibroblast growth factor (FGF-2) (Seeger and Rinas 1996), vascular endothelial growth factor (VEGF) (Fiebich et al. 1993), and bone morphogenetic protein-2 (BMP-2) (Vallejo and Rinas 2004), enzymes such as thrombin (Nordenman and Björk 1977), enzyme inhibitors such as antithrombin III (ATIII) (Miller-Andersson et al. 1974), and tyrosine-kinase growth factor receptors such as the FGF receptor (Perderiset et al. 1992) can be purified with a high level of purity.

Heparin affinity chromatography has also some disadvantages. Despite heparin is known for its broad binding specificity to a lot of different proteins, it is not possible to purify a heparin-binding protein from the cell lysate in one single step. It always needs at least one additional step for a complete purification process. Furthermore, heparin is recovered from mucosal tissue of slaughterhouse waste. It is possible that the slaughterhouse waste is infected by animal pathogens such as viruses or prions. Therefore, proteins could be contaminated with these pathogens if they are purified by heparin affinity chromatography (Farooqui 1980).

\section{Analysis of the heparin-protein interactions}

Since the discovery of heparin, several research groups have studied the interactions between heparin and heparin-binding proteins. Cardin and Weintraub started the first experiments to determine the heparin-binding domain (Cardin and Weintraub 1989). They examined four proteins (apolipoprotein B (ApoB), apolipoprotein $\mathrm{E}(\mathrm{ApoE})$, vitronectin $(\mathrm{Vn})$, and platelet factor 4 (PF-4)) for their similarities in their heparin-binding domains. Basic clusters with a density of high positive charge were detected. The acidic groups of heparin were electrostatically interacting with these basic clusters. Furthermore, Cardin and Weintraub discovered in these four proteins the two consensus sequences for heparin recognition [-X-B-B-X-B-X] and [-X-B-B-B-X-X$\mathrm{B}-\mathrm{X}-\mathrm{]}$. There, $\mathrm{X}$ stands for hydropathic residues (Ala, Gly, Ile, Leu or Tyr) and B stands for basic residues (Lys, Arg, and rarely His).

The consensus sequences were used for molecular modeling and were detected in several secondary structural conformations. The modeling experiments indicated that the basic amino acids are outside on one side of the $\beta$-strand and the hydropathic residues are inside the protein in the case of the $\beta$-strand conformation sequence [-X-B-B-X-B-X]. The sequence [-XB-B-B-X-X-B-X-] has an $\alpha$-helix conformation, where the basic amino acids are on one side of the helix and the hydropathic residues face the protein core (Cardin and Weintraub 1989; Torrent et al. 2012). By the help of the molecular modeling studies of Cardin and Weintraub, a third consensus sequence for heparin binding was found in the von Willebrand factor [-XB-B-B-X-X-B-B-B-X-X-B-B-X-]. This sequence was used to test further proteins for heparin binding. Unfortunately, the consensus sequences could not be identified in any other heparinbinding protein (Sobel et al. 1992). 
Table 1 Examples of heparinbinding proteins

\begin{tabular}{|c|c|c|}
\hline Nature & Heparin-binding protein & Source \\
\hline \multicolumn{3}{|c|}{ Cytokines/Growth factors } \\
\hline & BMP-2 & Ori et al. (2011) \\
\hline & FGF-1 & Schlessinger et al. (2000) \\
\hline & FGF-2 & Schlessinger et al. (2000) \\
\hline & Fibroblast growth factor receptor 1 (FGFR1) & Schlessinger et al. (2000) \\
\hline & FGFR2 & Schlessinger et al. (2000) \\
\hline & Hepatocyte growth factor & Muñoz and Linhardt (2004) \\
\hline & Heparin binding-epidermal growth factor (HB-EGF) & Aviezer and Yayon (1994) \\
\hline & Interleukin-1, $-2,-3,-4,-5,-7,-8,-10,-12$ & Koopmann et al. (1999) \\
\hline & VEGF-A 165 & Robinson et al. (2006) \\
\hline & Transforming growth factor- $\beta$ (TGF- $\beta$ ) & Coombe and Kett (2005) \\
\hline \multicolumn{3}{|c|}{ Lipid-binding proteins } \\
\hline & Annexin V & Capila et al. (2001) \\
\hline & Apopolipoprotein B (ApoB) & Cardin and Weintraub (1989) \\
\hline & ApoE & Dong et al. (2001) \\
\hline \multicolumn{3}{|c|}{ Adhesion proteins } \\
\hline & Fibronectin & Coombe and Kett (2005) \\
\hline & Vitronectin (Vn) & Cardin and Weintraub (1989) \\
\hline \multicolumn{3}{|c|}{ Chemokines } \\
\hline & Platelet factor 4 (PF4) & Imberty et al. (2007) \\
\hline & $\begin{array}{l}\text { Regulated on activation normal T cell expressed } \\
\text { and secreted (RANTES) }\end{array}$ & Handel et al. (2005) \\
\hline \multicolumn{3}{|c|}{ - } \\
\hline & AT III & Johnson and Huntington (2003) \\
\hline & Thrombin & Carter et al. (2005) \\
\hline
\end{tabular}

By further studies, it was detected that the conformation of the heparin-binding site is not important for the interactions but rather the distance of $\sim 20 \dot{A}$ between the basic amino acids (mainly arginines) (Margalit et al. 1993). In this gap, a pentasaccharide would fit. Furthermore, it was suggested that heparin is wrapping around the heparin-binding sides of the protein. This coiled-coil-like structure can cause changes in the protein conformation.

A few years later, Hileman et al. proposed another consensus sequence for heparin binding while using X-ray and NMR for the screening of acidic and basic fibroblast growth factor (FGF-1 and FGF-2) and transforming growth factor $\beta-1$ (TGF $\beta-1)$. The pattern is $[-T-X-X-B-$ $\mathrm{X}-\mathrm{X}-\mathrm{T}-\mathrm{B}-\mathrm{X}-\mathrm{X}-\mathrm{X}-\mathrm{T}-\mathrm{B}-\mathrm{B}-\mathrm{]}$ where $\mathrm{B}$ and $\mathrm{X}$ have the same meaning as already mentioned above, and $T$ stands for a turn (Hileman et al. 1998).

Torrent et al. determined a structural rather than a sequence motif comprising one polar (Asn, Gln, Thr, Tyr or Ser and fewer Arg or Lys) and two cationic residues (Arg or Lys) which was called "CPC Clip Motif" (Torrent et al. 2012). There, $C$ stands for cationic residues and $P$ stands for polar residues. The cationic and polar residues identified a clip-like structure in which heparin can be placed (Mosier et al. 2012; Dempewolf et al. 2013; Green et al. 2013). Within this motif, the cationic amino acids were responsible for the major interactions with heparin and the polar amino acid for the fine tuning. For this study, they screened 20 heparin-binding proteins for structural motifs that interact with heparin via electrostatic interactions, hydrogen bonding, and van der Waals bonds. It was found that the basic amino acids Arg and Lys were necessary for the hydrogen-bonding and electrostatic interactions with heparin. They confirmed the research of Cardin-Weintraub that Lys and Arg as well as Ala, Gly, Ile, Leu, or Tyr were essential in heparin binding. Otherwise, they could not detect a Cardin Weintraub motif in every heparin-binding protein they analyzed. Further, the CPC clip motif was also found in proteins which are indicated not to bind heparin (Torrent et al. 2012; Pulido et al. 2017). In Table 2, all motives are summarized.

Up to now, it is not completely explored which parts of heparin bind proteins and the other way round. The best way to characterize the interactions between proteins and heparin is with the help of crystal structures. 
Table 2 Comparison of the patterns of heparin-binding proteins

\begin{tabular}{lll}
\hline Pattern & Bound proteins & Source \\
\hline$[-X-B-B-X-B-X]$ and [-X-B-B-B-X-X-B-X-] & ApoB, ApoE, PF-4, Vn & Cardin and Weintraub (1989) \\
[-X-B-B-B-X-X-B-B-B-X-X-B-B-X-] & von Willebrand factor & Sobel et al. (1992) \\
[-T-X-X-B-X-X-T-B-X-X-X-T-B-B-] & FGF-1, FGF-2, TGF $\beta-3$ & Hileman et al. (1998) \\
Cation-Polar-Cation (CPC-Clip motif) & 20 heparin binding proteins & Torrent et al. (2012) \\
& (e.g., FGF-1, FGF-2) & \\
\hline
\end{tabular}

$X$ hydropathic residues like Ala, Gly, Ile, Leu or Tyr, $B$ basic residues like Lys, Arg or fewer His, $T$ turn, $C$ cationic residue like Lys or Arg, $P$ polar residue like Asn, Gln, Thr, Tyr or Ser and fewer Arg or Lys

\section{Crystal structures of heparin-protein complexes}

A couple of research groups are dealing with the proteinheparin interactions, whether it is for medical or biotechnological applications. Four proteins with a strong affinity to heparin are in the main focus. These include different types of biologically active proteins such as the cytokines FGF-1 (Zhu et al. 1993; DiGabriele et al. 1998) and FGF-2 (Faham et al. 1996; Pellegrini et al. 2000; Schlessinger et al. 2000), the serin protease thrombin (Li et al. 2004; Carter et al. 2005), and the glycoprotein ATIII (Mulloy and Linhardt 2001; Li et al. 2004; Coombe and Kett 2005; Xu and Esko 2014). These proteins differ not only in their protein class but also in their pI and molecular weight. The different research groups could not use heparin itself for their studies since it is a very heterogeneous molecule. Therefore, heparin-simulating molecules are used. The interactions between these heparin mimicry and the listed biologically active proteins are shown in Table 3.

\section{Crystal structure of the fibroblast growth factors-heparin complex}

Fibroblast growth factors ( 23 members) regulate cellular processes such as cell growth and cell differentiation. Their signal transduction system is omnipresent and important in the developmental process in embryos and the homeostasis in adults (Ye et al. 2001). The interaction with heparin enhances their bioactivity (DiGabriele et al. 1998).

FGF-1 was crystallized with a fully sulfated heparin decasaccharide to identify the interactions between FGF-1 and heparin (Table 3). Most of the interactions between FGF-1 and heparin were ionic caused by the basic residues of FGF-1 and the acidic sulfate and carboxylate groups of heparin (Table S1). Furthermore, FGF-1 interacts with five to six monosaccharides of opposite sites of the heparin fragment. Hence, no interactions are exactly alike and variations are in the interactions of FGF-1 and heparin (DiGabriele et al. 1998).

The results complied with other crystal structures in which sucrose octasulfate (SOS) (Zhu et al. 1993) or un/sulfated oligosaccharides were used to identify the sugar-binding side of FGF-1 (Ornitz et al. 1995; Faham et al. 1996).

It was further detected that Lys112 and Lys118 interacted twice with each sugar ring of sucrose octasulfate (Table 3). The furanose was bound two to three times by Arg 116 and Arg122 (Zhu et al. 1993).

A study with a decasaccharide consisting of five glucosamine and iduronic acid disaccharides endorsed these results (Table 3). It was detected that one decasaccharide bound two FGF-1 proteins. The binding site of the first FGF-1 consisted of polar and basic residues. FGF-1 interacted with six monosaccharides (IdoA-1 to GlcN-4). The second FGF-1 turned $120^{\circ}$ compared to the first FGF-1 and interacted with five monosaccharides (GlcN-1 to GlcN-3). As a result, the second FGF-1 interacted with heparin by different residues. Lys105, Trp107, Lys112, Arg119, Pro121, and Arg122 presented the heparin-binding domain. The heparin-binding sites differed in the residues Lys105, Trp107, and Pro121 (Pellegrini et al. 2000).

Different research groups studied the interactions between heparin and FGF-2. FGF-2 was crystallized with two homogenous fragments of heparin-a tetra- and a hexasaccharide (Table 3 ). The heparin fragments consisted of a concatenation of the same disaccharide, 2 - $O$-sulfo- $\alpha$-L-iduronic acid $1 \rightarrow 4$ linked to 6 - $O$ - sulfo- $N$ - sulfo- $\alpha$ - D-glucosamine $(\rightarrow$ 4]IdoA-( $\left.2 \mathrm{OSO}_{3}\right)-\beta(1 \rightarrow 4)-\mathrm{GlcNSO}_{3}-\left(6 \mathrm{OSO}_{3}\right)[1 \rightarrow)$ (Fig. 1). The hexasaccharide had three disaccharides and the tetrasaccharide two disaccharides. Both heparin fragments bound similar residues. Most of the specific interactions between heparin and FGF-2 were mediated by negatively charged groups (Table S2). FGF-2 had a higher binding affinity to the hexasaccharide which is probably caused by the larger contact region. It can be concluded that the residues which bound the second and third ring of both saccharides belong to the main heparin-binding site whereas the residues which bound the fifth and sixth ring belong to the minor heparin-binding site (Faham et al. 1996).

The pentasaccharide $\mathrm{GlcNSO}_{3}-\left(6-\mathrm{OSO}_{3}\right)-\alpha(1 \rightarrow 4)$ $\mathrm{IdoA}-\alpha(1 \rightarrow 4)-\mathrm{GlcNSO}_{3}-\left(2-\mathrm{OSO}_{3}\right)-\left(6-\mathrm{OSO}_{3}\right)-\alpha(1 \rightarrow 4)-$ IdoA- $\left(3-\mathrm{OSO}_{3}\right)-\alpha(1 \rightarrow 4)-\mathrm{GlcNSO}_{3}-\left(6-\mathrm{OSO}_{3}\right)$ (Table 3$)$ was also used to identify the heparin-binding domain of FGF-2 and determined similar. Arg81 bound indirectly heparin 
Table 3 Characteristics of protein-heparin interactions

\begin{tabular}{llclll}
\hline & & & & \\
Pwotein & $\mathrm{pI}$ & $\mathrm{kD}$ & Heparin mimic & Structure of heparin mimic & Further \\
information & Source
\end{tabular}

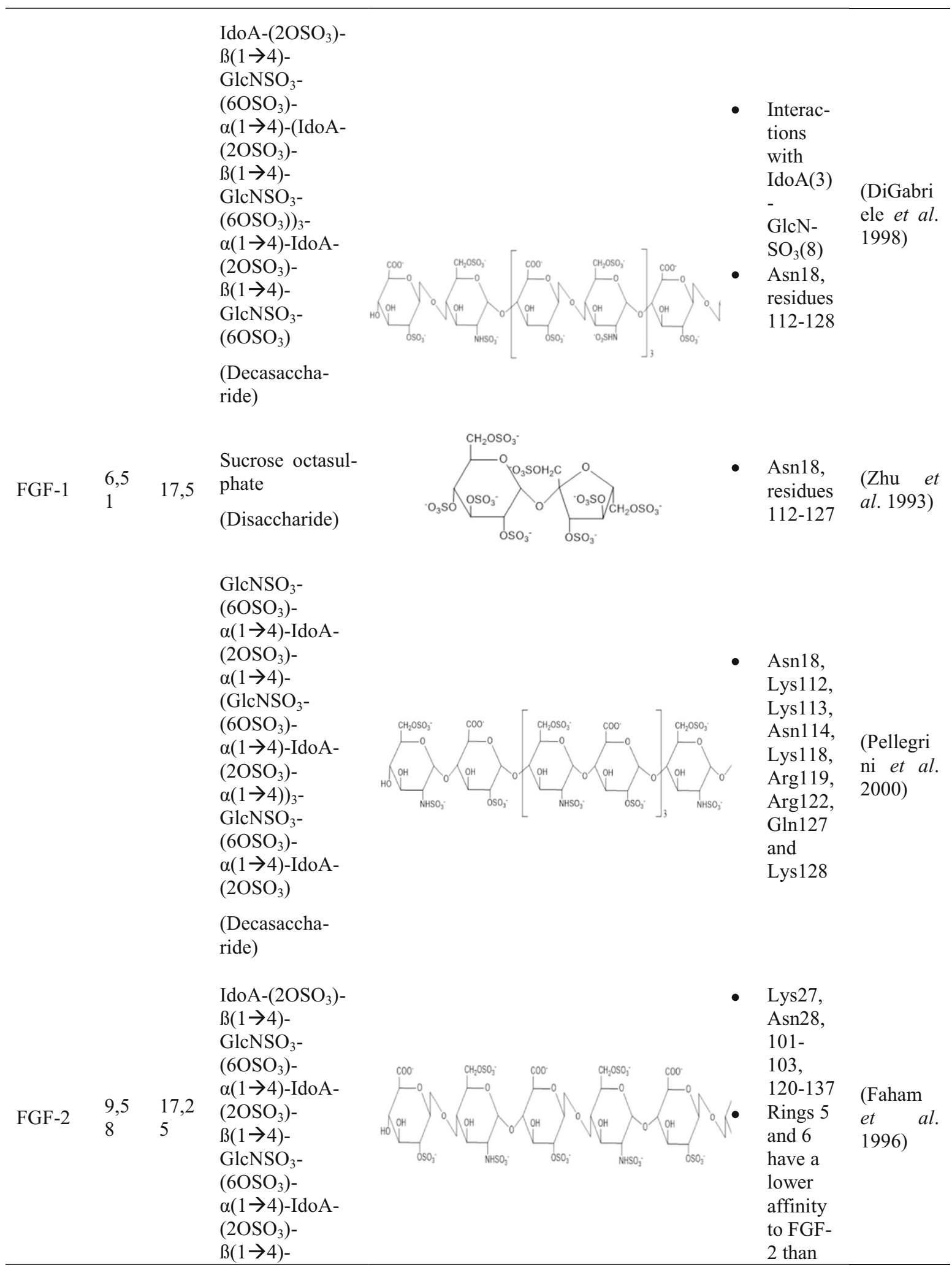




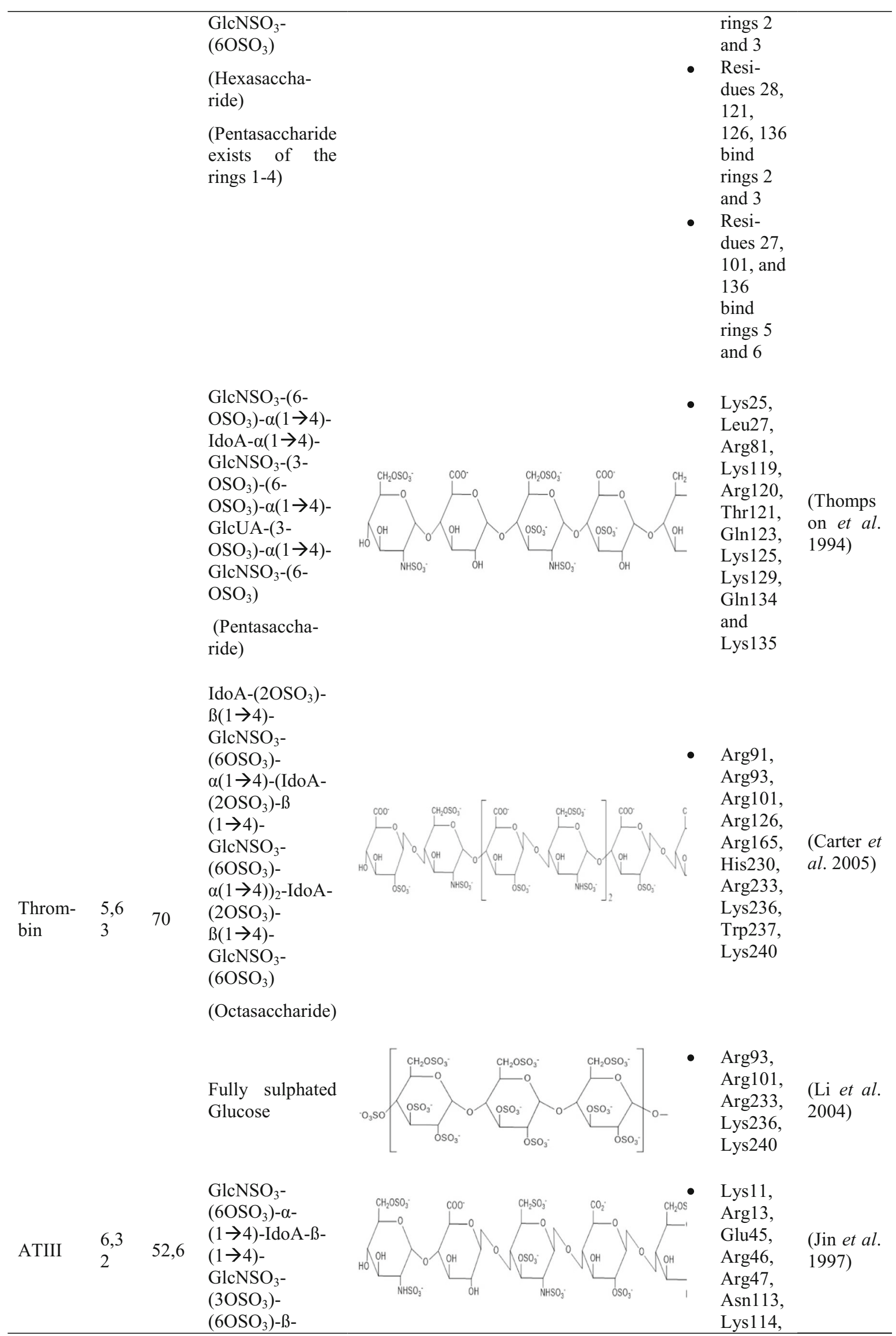




$\begin{array}{ll}(1 \rightarrow 4)-G l c U A- & \text { Lys125 } \\ \left(2 \mathrm{OSO}_{3}\right)-\beta- & \text { and } \\ (1 \rightarrow 4)-\quad \text { GlcN- } & \text { Arg129 }\end{array}$

$\mathrm{SO}_{3}-\left(6 \mathrm{OSO}_{3}\right)$

(Pentasaccha-

ride)

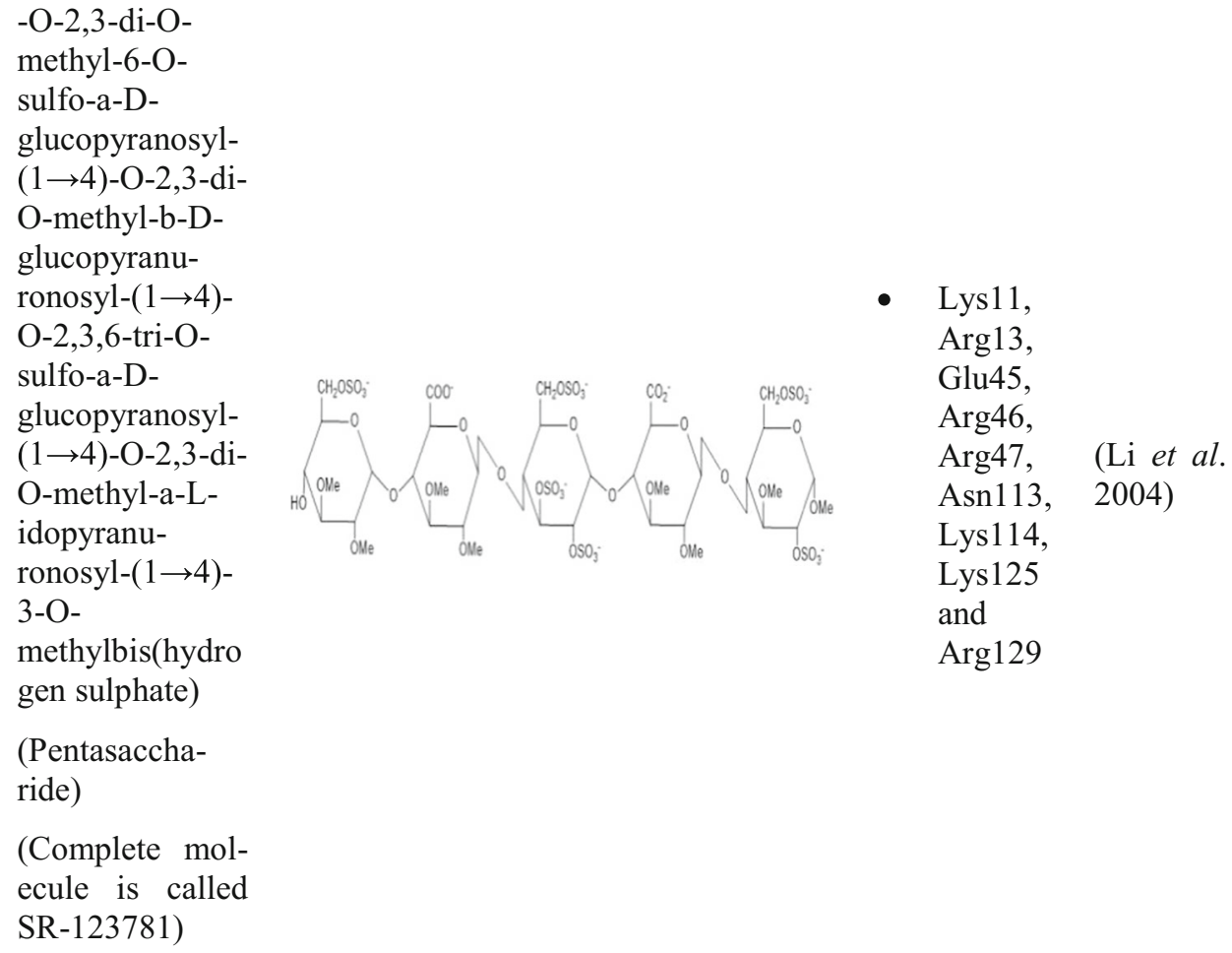

(Pentasaccharide)

(Complete molecule is called SR-123781)

$\mathrm{Glc}_{\mathrm{NSO}}=\mathrm{N}$-sulfo- $\alpha$-D-glucosamine, $\mathrm{GlcNSO}_{3}-\left(6 \mathrm{OSO}_{3}\right)=6$ - $\mathrm{O}$-sulfo- $\mathrm{N}$-sulfo- $\alpha$-D-glucosamine, $\mathrm{GlcNSO}_{3}-\left(3 \mathrm{OSO}_{3}\right)-\left(6 \mathrm{OSO}_{3}\right)=3,6-\mathrm{O}$-sulfo- $\mathrm{N}$-sulfo$\alpha$-D-glucosamine, IdoA = $\alpha$-L-iduronic acid, IdoA-(2-OSO3) = 2-O-sulfo- $\alpha$-L-iduronic acid, GlcUA-(3-OSO3) $=3$ - $O$-sulfo- $\alpha$-D-glucuronic acid

through a water molecule. Further experiments showed that Lys125 is the most important residue for heparin-FGF-2 interactions. It was detected that the heparin-protein interactions are also mediated by hydrophobic interactions, hydrogen bonding, and van der Waals forces (Thompson et al. 1994; Torrent et al. 2012). Accordingly, not sulfated heparin fragments like carboxyl and hydroxyl groups can also interact with protein residues (Ornitz et al. 1995).

Recapitulating, the heparin-binding domain of FGF-1 and FGF-2 featured similarities which could be attributed to the fact that their structure identity is higher than $50 \%$ (Galzie et al. 1997). Furthermore, Zhu detected that the residues Lys 112 and Lys118 from FGF-1 are the analogous residues of Lys119 and Lys125 from FGF-2. These residues are important in the protein-SOS-interactions (Zhu et al. 1993).

\section{Crystal structure of the thrombin-heparin complex}

The heterodimer thrombin is a serine protease which cleaves soluble fibrinogen. This leads to the development of polymerogenic fibrin and causes the fibrin clot and therefore blood coagulation. Thrombin is important in the process of wound healing and inflammations. The normal blood flow is
Fig. 2 Structure of the pentasaccharide fondaparinux

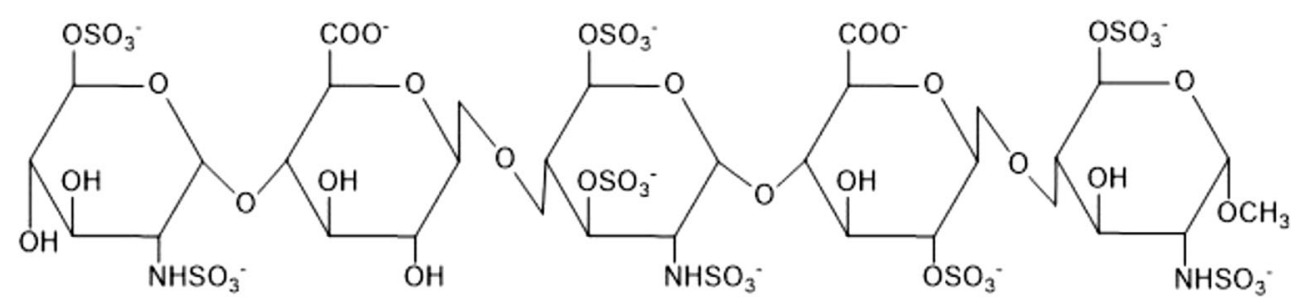




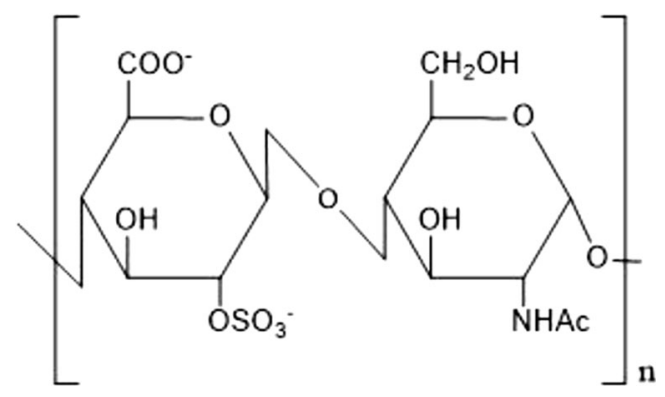

Fig. 3 Structure of the heparin precursor heparosan

maintained when thrombin is inhibited by antithrombin (AT) or heparin through an irreversible method (Carter et al. 2005).

The crystal structure of thrombin discloses two cationic patches on the surface. These are identified as two anionbinding exosites. Exosite I is the fibrinogen recognition, exosite and exosite II the commonly believed heparinbinding exosite.

To identify the heparin-thrombin interactions, an octasaccharide heparin fragment was used. The saccharide consisted of a linkage of four disaccharides (IdoA- $\left(2 \mathrm{OSO}_{3}\right)$ GlcNS- $\left.\left(6 \mathrm{SOSO}_{3}\right)\right)_{4}$ (Table 3). Each of the two heparin molecules was crystallized with two thrombin monomers. All four thrombin monomers had a similar conformation. Two monomers interacted the most with six monosaccharides of heparin. The other two interacted with five monosaccharides. The experiments showed that the sulfate groups of heparin were mostly interacting with thrombin (Table S3). These residues are negatively charged and interacting with basic amino acids of thrombin (Arg, Lys, His). Recapitulating, these kinds of interaction are of ionic nature (Carter et al. 2005).

Further studies identified also Lys 235 as a binding residue (Xu and Esko 2014). By mutagenesis, different research groups detected the importance of this single basic residue. Following ranking shows the importance of the different residues of thrombin in heparin-binding: Arg93 > Lys236> Lys240 > Arg101 > Arg233 (Sheehan and Sadler 1994; Gan et al. 1994; Tsiang et al. 1997; Carter et al. 2005).

Three glucose units covered with ten sulfate groups were also used to study the protein residues interacting with heparin (Table 3). The results endorsed the research of Carter. Arg93, Arg101, Arg233, Lys236, and Lys240 were involved in the interactions with the heparin mimic. Arg93 interacted three times with the heparin mimic, Lys236 twice, Arg101 and Arg233 once, and Lys240 could form three interactions (was not fully modeled) (Table S4) (Li et al. 2004).

\section{Crystal structure of the ATIII-heparin complex}

ATIII is a serpin and inhibits serine proteases such as thrombin. It is one of the most important inhibitors of the blood coagulation and circulates with a low reactivity but in a high concentration in the bloodstream. Heparin supports and catalyzes the activity of ATIII by interaction (Mulloy and Linhardt 2001).

It was shown that the unique pentasaccharide sequence $\mathrm{GlcNSO}_{3}-\left(6-\mathrm{OSO}_{3}\right)-\alpha(1 \rightarrow 4)-\mathrm{IdoA}-\alpha(1 \rightarrow 4)-\mathrm{GlcNSO}_{3}-(3-$ $\left.\mathrm{OSO}_{3}\right)-\left(6-\mathrm{OSO}_{3}\right)-\alpha(1 \rightarrow 4)-$ GlcUA-$\left(2-\mathrm{OSO}_{3}\right)-\alpha(1 \rightarrow 4)$ $\mathrm{GlcNSO}_{3}-\left(6-\mathrm{OSO}_{3}\right)-\mathrm{OH}$ bound ATIII with a high affinity (Table 3). The third monosaccharide (glucosamine) was modified with a 3-O-sulfate. This modification is very unusual but probably important for the high affinity to ATIII (Lindahl et al. 1984). Studies revealed that ATIII bound heparin with a 1000-fold higher affinity than heparin without this modification (Rosenberg 1978). This pentasaccharide is very rare and is present in just one third of heparin chains (Casu et al. 1981; Riesenfeld et al. 1981).

In further studies, this pentasaccharide was also used to determine the interactions between heparin and ATIII (Table 3). It was shown that the residues Lys11, Arg13, Asn45, Arg46, Arg47, Glu113, Lys114, Lys125, and Arg129 were involved in the interactions with the heparin fragment (Jin et al. 1997).

Another working group explored also the interactions between heparin and ATIII with a similar pentasaccharide (Table 3). The results reinforced the previous studies and are summarized in Table S5. The interactions between heparin and ATIII were based on electrostatic interactions and hydrogen bonds ( $\mathrm{Li}$ et al. 2004).

\section{Conclusion of the crystal structure studies}

The four examples represent three different protein classes additionally with a different molecular weight and an individual pI. In each case, the heparin-binding domain consisted of a cluster of basic amino acids (Arg, Lys). These clusters are not based on the amino acid sequence but probably on their secondary structure. Mostly, some surrounded amino acids form one part of the heparinbinding domain. The entire domain exists of at least two parts across the whole protein.

The analysis of the heparin fragments reveal that the sulfate residues are mostly involved in the interactions with the proteins. It is secondary whether it is an $O$-sulfated or $N$-sulfated residue. The carboxyl and hydroxyl groups are less involved in the interactions.

Recapitulating, the analysis of the heparin-binding domain emerges that the heparin-binding domain is not made of a definite pattern. The heparin-protein interactions are not only electrostatic. It is a combination of different interactions which leads to the specificity of heparin to the heparin-binding proteins. 


\section{Strategies to replace animal-derived heparin}

Over \$3 billion of pharmaceutical heparin is sold every year. The demand is about 100 metric tons per year and is expected to further increase. However, the provision of the animal tissue is limited and hence also for heparin. Furthermore, heparin as an animal-derived material involves the risk of contaminations such as viruses and prions. Additionally, in 2008, heparin was contaminated with oversulfated GAGs from pigs in China. This heparin contamination crisis caused the death of 100 people in the USA alone (Guerrini et al. 2008). In addition, the heparin production is subject to strict quality control and the validation of effective GMP implementations. This results in a huge interest on the development of an alternative production of heparin from non-animal origin. These include the chemical and chemoenzymatical synthesis or the bioengineering of heparin. Furthermore, the heparin affinity chromatography could be replaced by already-established chromatography methods.

\section{Chemical synthesized heparin}

In 2002, a synthetic pentasaccharide of heparin went on sale. The substance is called Fondaparinux (Fig. 2) and binds the coagulation factor AT-III which inhibits the formation of thrombin as well as the thrombus growth and disturbs the coagulation cascade. The name of the drug is Arixtra (marketed within the US by Dr. Reddy's Laboratories). However, the production of this drug is very expensive regarding the multistep chemical synthesis, the expensive materials, and the low yield. This led to a restricted clinical application (Petitou and Van Boeckel 2004; Liu and Linhardt 2014). Furthermore, this drug is specific just for the binding of ATIII and does not possess other significant pharmacological characteristics of heparin. Moreover, Arixtra has a longer half-life than heparin and eliminates the effect by the antagonist protamine which could lead to uncontrolled bleeding (Buller et al. 2007; Zulueta et al. 2013).

\section{Chemoenzymatic heparin}

The chemoenzymatic synthesis of heparin is based on its biosynthetic pathway. It is a heparin analogous pentasaccharide which is not extracted from intestines. That pentasaccharide binds ATIII and leads to anticoagulation. The "neoheparin" is produced by a combination of biosynthetic and chemoenzymatic modifications of a polysaccharide produced from the strain Escherichia coli K5 (E. coli $\mathrm{K} 5$ ). This strain produces naturally the unsulfated precursor of heparin $\left([\mathrm{GlcA} \beta-(1 \rightarrow 4) \mathrm{GlcNAc} \alpha(1 \rightarrow 4)]_{\mathrm{n}}\right.$, the socalled Heparosan (Fig. 3)) (Lindahl et al. 2005; Zulueta et al. 2013).

Heparosan is $N$-deacetylated and $N$-sulfated in some steps and further modificated by recombinant $\mathrm{C} 5$ epimerases and $\mathrm{O}$ - sulfotransferases. It is a six-step process with a $60 \%$ recovery rate of the polysaccharide, and the yield is at gram scale (Lindahl et al. 2005). Disadvantages of this process are the limitation of the start material for an up-scaling. Furthermore, the specificity of the enzymes could vary the composition of “neoheparin" (Masuko and Linhardt 2012; Fu et al. 2016).

\section{Bioengineered heparin}

A promising idea is the production of pharmaceutical heparin in mammalian cell systems such as the Chinese hamster ovary (CHO) cell system (Baik et al. 2012). The CHO cell system has been intensively studied for the production of pharmaceutical products such as recombinant enzymes, hormones, and monoclonal antibodies. CHO cell systems have also the ability to produce non-protein pharmaceuticals such as heparin. These systems are characterized by their natural glycosylation of CHO cell proteins and are safe regarding potential biological contaminations and easy to scale up (Baik et al. 2012).

$\mathrm{CHO}$ cells produce heparan sulfate (HS) which consists of the same disaccharides as heparin but less sulfated. Nevertheless, HS and heparin share the same biosynthetic pathway and HS is such a heparin, an anticoagulant but with a lower activity (Robinson et al. 1978). For the heparin synthesis, HS can be used as precursor. $\mathrm{CHO}$ cells provide most of the enzymes which are needed for the production of bioengineered heparin. They do not express mouse heparin sulfate 3-O-sulfotransferase 1 (Hs3st1) und $N$-deacetylase $/ N$ sulfotransferase (NDST2) (Xu et al. 2012; Fu et al. 2016). Both enzymes are involved in the synthesis of the ATbinding pentasaccharide and $N$-sulfation of GlcNAc. Therefore, they are relevant for the anticoagulant properties of heparin (Sugahara and Kitagawa 2002). For the production of heparin in CHO cells, the genes of Hs3st1 and NDST2 have to be transfected into $\mathrm{CHO}$ host.

Disadvantageous is that the engineered heparin does not have the same trisulfated structure which is common in animal-derived heparin. The expressed heparin showed a higher level of anticoagulant activity than in not transfected cell lines. Nevertheless, the activity of bioengineered heparin compared to animal-derived heparin was inadequate (Baik et al. 2012).

\section{Replacement of heparin in affinity chromatography systems}

Several working groups established already other methods to purify heparin-binding proteins with animal-component free processes. The recombinant human BMP-2 was often used as model protein.

Sharapova et al. published one method to purify BMP-2 without heparin affinity chromatography. A strong cation exchange chromatography resin was used. 
The protein was produced in inclusion bodies of E. coli. BMP-2 in inclusion bodies was first denatured and solubilized. The purification of the protein was performed with the refolding solution in one single step by the cation exchange column S-sepharose FastFlow. BMP-2 was biological active and had a purity of $95 \%$ (Sharapova et al. 2010).

A further method to purify BMP-2 without heparin showed Guo et al. In this study, BMP-2 was purified by a two-step hydrophobic interaction chromatography (HIC). Both steps were performed by a Phenyl Sepharose Fast Flow High Sub column.

BMP-2 was produced in inclusion bodies of E. coli. The protein was solubilized and refolded prior to the two purification steps. There was no need of a buffer exchange since HIC starts at a high salt concentration. The first chromatography step is used as concentration step of BMP-2 from the refolding solution. The second step functions as purification step. The pooled elution fractions of the first chromatography step were applied to the column. This time, a higher $\mathrm{NaCl}$ concentration and 5\% $\mathrm{N}, \mathrm{N}$-dimethylformamide (DMF) were added. DMF disrupts the interactions between protein and ligand and leads to an elution of BMP-2 in the flow-through during rebalancing step. The protein was purified with more than $95 \%$ and biological active. The purification yield was higher than $20 \%$ (Guo et al. 2012).

Rane et al. (2013) purified BMP-2 by a weak cation exchange resin and polished by a size exclusion column. The protein was also produced in inclusion bodies of $E$. coli. After solubilization, BMP-2 was on-column refolded on a weak cation exchange resin with carboxylic acid as functional group. After a buffer exchange, BMP-2 was polished by a size exclusion column. The purity of the biological active protein was higher than $90 \%$. Disadvantageous is the low yield of $14 \%$ (Rane et al. 2013).

In addition, Gieseler et al. published a method to purify BMP-2 by mixed-mode membrane chromatography (MMC). This membrane adsorber consists of reinforced cellulose membrane packed with cation-exchange groups and hydrophobic ligands. The forming interactions can be hydrophobic and ionic. Furthermore, this MMC is salt tolerant which is advantageous for purifying salt containing BMP-2 refolding mixture.

BMP-2 was produced in inclusion bodies of E. coli. After denaturation and solubilization of the inclusion bodies, the refolding solution was directly applied to the MMC. The purity of the biological active protein was higher than $90 \%$. A disadvantage of this method is the low recovery rate of rhBMP-2 caused by buffer exchange or dialysis (Gieseler et al. 2017).

These publications demonstrated that animal-componentfree methods exist at least in the case of BMP-2. All methods resulted in a biological active protein and a purity of more than $90 \%$. Best results were performed by the strong cation exchange chromatography (Sharapova et al. 2010) and by HIC (Guo et al. 2012) with a purity of at least $95 \%$. For comparison, BMP-2 has a purity of almost $100 \%$ after heparin-affinity chromatography (Ruppert et al. 1996; Quaas et al. 2018).

Further model proteins were FGF-1 and FGFR from the cell lysate where Batra et al. showed a way to purify these proteins by a weak cation exchanger. They used an Amberlite cation exchange resin (IRC) 50. The compounds of this resin are copolymerized methacrylic acid and divinylbenzene. Therefore, the main functional groups are carboxyl groups and the minor groups are methyl and phenyl groups. The forming interactions can be hydrophilic and hydrophobic and thus provide affinity and hydrophobic binding sites for the analyte. This method is timesaving and inexpensive compared to heparin affinity chromatography.

FGF-1 and FGFR were both recombinant expressed by E. coli. While FGF-1 remains soluble after cell growth, FGFR is present in inclusion bodies. After the chromatography step, the purity of both proteins was about $98 \%$. The total yield of FGF-1 was $30 \mathrm{mg} / \mathrm{L}$ which is similar to the yield after using heparin-affinity chromatography (32 mg/L). Additionally, FGF-1 showed biological activity after purification. FGFR had a yield higher $(24 \mathrm{mg} / \mathrm{L})$ than after conventional purification methods $(20 \mathrm{mg} / \mathrm{L})$ (Batra et al. 2011).

Additionally, Pizarro et al. used a further method to purify a heparin-binding protein without heparin. The recombinant human vascular endothelial growth factor A165 (VEGF) was produced in inclusion bodies of E. coli. After solubilization and refolding, VEGF was purified by three chromatography steps.

The first chromatography step functions as a capture step of VEGF. The protein was applied to a multimodal cation exchanger (Capto ${ }^{\mathrm{TM}} \mathrm{MMC}$ ) because of the high $\mathrm{pH}$ of the refolded VEGF. This column has the characteristics of a weak cation exchanger but is featured with further ligand structures. Additionally to the electrostatic interactions, hydrogen bonding and hydrophobic and thiophilic interactions can also be formed.

For the next step, a strong cation exchange column (SP Sepaharose High Performance) was used to remove the host cell impurities and product variants. In the last step, the sample was applied to a hydrophobic interaction chromatography column (Phenyl Sepharose ${ }^{\mathrm{TM}} 6$ Fast Flo-low substitution) to polish the protein. Host cell impurities and aggregates below target levels were removed in this step. The purity was higher than $99 \%$ and the protein was also bioactive (Pizarro et al. 2010). 


\section{Concluding remarks and future prospects}

Heparin binds specifically to a variety of biotechnological important proteins. This makes heparin affinity chromatography an important method for purifying several proteins. It is comfortable to use and does not require any additional protein tags like other affinity chromatography methods. However, heparin chromatography is limited by the unregulated production of heparin out of slaughterhouse waste. As a result, it is inapplicable for GMP-compliant purifications. As heparin is very heterogeneous and no definite pattern of the proteinbinding region is known, heparin is still not replaced in affinity chromatography systems. Nevertheless, in this review, two possibilities for the heparin affinity chromatography with nonanimal-derived heparin are discussed.

The first opportunity is the production of animalcomponent free heparin by chemical or chemoenzymatic synthesis or by metabolic engineered $\mathrm{CHO}$ cells. However, these bioengineered heparins have been employed only for pharmaceutical reasons and structure analysis. Although promising to our knowledge, there is no study about using bioengineered heparin for purification methods up to now.

The second opportunity is the utilization of already known chromatography techniques to replace heparin chromatography for purifying proteins. At least six research groups examined already established chromatography methods to purify heparin-binding proteins. Single-step purification (IRC or MMC) and multi-step purification (HIC or a combination of Capto ${ }^{\mathrm{TM}} \mathrm{MMC}$, CEX, and HIC) showed a similar purification grade compared to the purification by heparin affinity chromatography. The special feature of heparin is its specificity to various proteins. The interactions are not only electrostatic but also a combination of different interactions (van der Waals forces, hydrogen bonds, hydrophobic, and thiophilic interactions). These characteristics were utilized for the development of new purification strategies. It must be noted that most of the protein samples were purified from refolded inclusion bodies. These proteins are of a higher purity than soluble expressed proteins. Therefore, these methods should be first tested for their applicability for other heparin-binding proteins especially for soluble proteins.

Funding The authors gratefully acknowledge funding through the Forschergruppe "Gradierte Implantate" FOR2180 and the Exzellenzcluster "Rebirth" EXC62, both Deutsche Forschungsgemeinschaft (DFG).

\section{Compliance with ethical standards}

Conflict of interest The authors declare that they have no conflict of interest.

Ethical approval This article does not contain any studies with human participants or animals performed by any of the authors.
Open Access This article is distributed under the terms of the Creative Commons Attribution 4.0 International License (http:// creativecommons.org/licenses/by/4.0/), which permits unrestricted use, distribution, and reproduction in any medium, provided you give appropriate credit to the original author(s) and the source, provide a link to the Creative Commons license, and indicate if changes were made.

\section{References}

Aviezer D, Yayon A (1994) Heparin-dependent binding and autophosphorylation of epidermal growth factor (EGF) receptor by heparinbinding EGF-like growth factor but not by EGF. Proc Natl Acad Sci U S A 91:12173-12177. https://doi.org/10.1073/pnas.91.25.12173

Baik JY, Gasimli L, Yang B, Datta P, Zhang F, Glass CA, Esko JD, Linhardt RJ, Sharfstein ST (2012) Metabolic engineering of Chinese hamster ovary cells: towards a bioengineered heparin. Metab Eng 14:81-90. https://doi.org/10.1016/j.ymben.2012.01.008

Batra S, Sahi N, Mikulcik K, Shockley H, Turner C, Laux Z, Badwaik VD, Conte E, Rajalingam D (2011) Efficient and inexpensive method for purification of heparin binding proteins. J Chromatogr B Anal Technol Biomed Life Sci 879:2437-2442. https://doi.org/10.1016/j. jchromb.2011.06.047

Best CH (1959) Preparation of heparin and its use in the first clinical cases. Circulation 19:79-86. https://doi.org/10.1161/01.CIR.19.1.79

Buller HR, Cohen AT, Davidson B, Decousus H, Gallus AS, Gent M, Pillion G, Piovella F, Prins MH, Raskob GE (2007) Idraparinux versus standard therapy for venous thromboembolic disease. $\mathrm{N}$ Engl J Med 357:1094-1104. https://doi.org/10.1056/ NEJMoa064247

Capila I, Linhardt RJ (2002) Heparin-protein interactions. Angew Chemie Int Ed 41:390-412. https://doi.org/10.1002/15213773(20020201)41:3<390::AID-ANIE390>3.0.CO;2-B

Capila I, Hernáiz MJ, Mo YD, Mealy TR, Campos B, Dedman JR, Linhardt RJ, Seaton BA (2001) Annexin V-heparin oligosaccharide complex suggests heparan sulfate-mediated assembly on cell surfaces. Structure 9:57-64. https://doi.org/10.1016/S0969-2126(00)00549-9

Cardin AD, Weintraub HJ (1989) Molecular modeling of proteinglycosaminoglycan interactions. Arteriosclerosis 9:21-32. https:// doi.org/10.1161/01.ATV.9.1.21

Carter WJ, Cama E, Huntington JA (2005) Crystal structure of thrombin bound to heparin. J Biol Chem 280:2745-2749. https://doi.org/10. 1074/jbc.M411606200

Casu B, Oreste P, Torri G, Zoppetti G, Choay J, Lormeau JC, Petitou M, Sinäy P (1981) The structure of heparin oligosaccharide fragments with high anti-(factor Xa) activity containing the minimal antithrombin III-binding sequence. Chemical and 13C nuclear-magneticresonance studies. Biochem J 197:599-609

Coombe DR, Kett WC (2005) Heparan sulfate-protein interactions: therapeutic potential through structure-function insights. Cell Mol Life Sci 62:410-424. https://doi.org/10.1007/s00018-004-4293-7

Dempewolf C, Morris J, Chopra M, Jayanthi S, Kumar TKS, Li WN (2013) Identification of consensus glycosaminoglycan binding strings in proteins. 2013 Int Conf Inf Sci Appl ICISA 2013. https://doi.org/10.1109/ICISA.2013.6579411

DiGabriele AD, Lax I, Chen DI, Svahn CM, Jaye M, Schlessinger J, Hendrickson WA (1998) Structure of a heparin-linked biologically active dimer of fibroblast growth factor. Nature 393:812-817. https://doi.org/10.1038/31741

Dong J, Peters-Libeu CA, Weisgraber KH, Segelke BW, Rupp B, Capila I, Hernáiz MJ, LeBrun LA, Linhardt RJ (2001) Interaction of the Nterminal domain of apolipoprotein E4 with heparin. Biochemistry 40:2826-2834. https://doi.org/10.1021/bi002417n 
Esko JD, Linhardt RJ (2009) Proteins that bind sulfated glycosaminoglycans In: essentials of Glycobiology, 3rd edn. Cold Spring Harbor Laboratory Press,

Faham S, Hileman RE, Fromm JR, Linhardt RJ, Rees DC (1996) Heparin structure and interactions with basic fibroblast growth factor. Science 271(80):1116-1120. https://doi.org/10.1126/science.271. 5252.1116

Farooqui AA (1980) Purification of enzymes by heparin-sepharose affinity chromatography. J Chromatogr A 184:335-345. https://doi.org/ 10.1016/S0021-9673(00)89004-4

Fiebich BL, Jager B, Schollmann C, Weindel K, Wilting J, Kochs G, Marme D, Hug H, Weich HA (1993) Synthesis and assembly of functionally active human vascular endothelial growth factor homodimers in insect cells. Eur J Biochem 211:19-26

Fu L, Suflita M, Linhardt RJ (2016) Bioengineered heparins and heparan sulfates. Adv Drug Deliv Rev 97:237-249. https://doi.org/10.1016/ j.addr.2015.11.002

Galzie Z, Kinsella AR, Smith JA (1997) Fibroblast growth factors and their receptors. Biochem Cell Biol 75:669-685

Gan ZR, Li Y, Chen Z, Lewis SD, Shafer JA (1994) Identification of basic amino acid residues in thrombin essential for heparin-catalyzed inactivation by antithrombin III. J Biol Chem 269:1301-1305

Gandhi NS, Mancera RL (2008) The structure of glycosaminoglycans and their interactions with proteins. Chem Biol Drug Des 72:455482. https://doi.org/10.1111/j.1747-0285.2008.00741.x

Gieseler G, Pepelanova I, Stuckenberg L, Villain L, Nölle V, Odenthal U, Beutel S, Rinas U, Scheper T (2017) Purification of bone morphogenetic protein-2 from refolding mixtures using mixed-mode membrane chromatography. Appl Microbiol Biotechnol 101:123-130. https://doi.org/10.1007/s00253-016-7784-1

Green JV, Orsborn KI, Zhang M, Tan QKG, Greis KD, Porollo A, Andes DR, Long Lu J, Hostetter MK (2013) Heparin-binding motifs and biofilm formation by Candida albicans. J Infect Dis 208:1695-1704. https://doi.org/10.1093/infdis/jit391

Guan D, Chen Z (2014) Challenges and recent advances in affinity purification of tag-free proteins. Biotechnol Lett 36:1391-1406. https:// doi.org/10.1007/s10529-014-1509-2

Guerrini M, Beccati D, Shriver Z, Naggi A, Viswanathan K, Bisio A, Capila I, Lansing JC, Guglieri S, Fraser B, Al-Hakim A, Gunay NS, Zhang Z, Robinson L, Buhse L, Nasr M, Woodcock J, Langer R, Venkataraman G, Linhardt RJ, Casu B, Torri G, Sasisekharan R (2008) Oversulfated chondroitin sulfate is a contaminant in heparin associated with adverse clinical events. Nat Biotechnol 26:669-675. https://doi.org/10.1038/nbt1407

Guo W, Zhu X, Cai J, Huang L, Cen P, Xu Z (2012) Refolding and two-step purification by hydrophobic interaction chromatography of recombinant human bone morphogenetic protein-2 from Escherichia coli. Process Biochem 47:960-967. https://doi.org/10.1016/j.procbio.2012.03.003

Handel TM, Johnson Z, Crown SE, Lau EK, Sweeney M, Proudfoot AE (2005) Regulation of protein function by glycosaminoglycans - as exemplified by chemokines. Annu Rev Biochem 74:385-410. https://doi.org/10.1146/annurev.biochem.72.121801.161747

Hileman RE, Fromm JR, Weiler JM, Linhardt RJ (1998) Glycosaminoglycan-protein interactions: definition of consensus sites in glycosaminoglycan binding proteins. BioEssays 20:156167. https://doi.org/10.1002/(SICI)1521-1878(199802)20:2<156:: AID-BIES8>3.0.CO;2-R

Imberty A, Lortat-Jacob H, Pérez S (2007) Structural view of glycosaminoglycan-protein interactions. Carbohydr Res 342:430 439. https://doi.org/10.1016/j.carres.2006.12.019

Jin L, Abrahams JP, Skinner R, Petitou M, Pike RN, Carrell RW (1997) The anticoagulant activation of antithrombin by heparin. Med Sci 94:14683-14688. https://doi.org/10.1073/pnas.94.26.14683

Johnson DJD, Huntington JA (2003) Crystal structure of antithrombin in a heparin-bound intermediate state. Biochemistry 42:8712-8719. https://doi.org/10.1021/bi034524y
Jorpes E, Bergström S (1936) Der Aminozucker des Heparins. Hoppe Seylers Z Physiol Chem 244:253-256. https://doi.org/10.1515/ bchm2.1936.244.5.253

Koopmann W, Ediriwickrema C, Krangel MS (1999) Structure and function of the glycosaminoglycan binding site of chemokine macrophage inflammatory protein-1b. J Immunol 163:2120-2127

Langer R, Linhardt R, Hoffberg S, Larsen A, Cooney C, Tapper D, Klein M (1982) An enzymatic system for removing heparin in extracorporeal therapy. Science 217(80):261-263. https://doi.org/10.1126/ science.7089564

Li W, Johnson DJD, Esmon CT, Huntington JA (2004) Structure of the antithrombin-thrombin-heparin ternary complex reveals the antithrombotic mechanism of heparin. Nat Struct Mol Biol 11:857862. https://doi.org/10.1038/nsmb811

Lindahl U, Thunberg L, Backstrom G, Riesenfeld J, Nordling K, Björk I (1984) Extension and structural variability of the antithrombinbinding sequence in heparin. J Biol Chem 259:12368-12376

Lindahl U, Li J-P, Kusche-Gullberg M, Salmivirta M, Alaranta S, Veromaa T, Emeis J, Roberts I, Taylor C, Oreste P, Zoppetti G, Naggi A, Torri G, Casu B (2005) Generation of "Neoheparin" from E. coli K5 capsular polysaccharide. J Med Chem 48:349-352. https://doi.org/10.1021/jm049812m

Linhardt RJ, Gunay NS (1999) Production and chemical processing of low molecular weight heparins. Semin Thromb Hemost 25:5-16

Liu J, Linhardt RJ (2014) Chemoenzymatic synthesis of heparan sulfate and heparin. Nat Prod Rep 31:1676-1685. https://doi.org/10.1039/ C4NP00076E

Liu H, Zhang Z, Linhardt RJ (2009) Lessons learned from the contamination of heparin. Nat Prod Rep 26:313-321. https://doi.org/10. 1039/b819896a

Marcum JA (1997) The development of heparin in Toronto. J Hist Med Allied Sci 52:310-337

Margalit H, Fischer N, Ben-Sasson SA (1993) Comparative analysis of structurally defined heparin binding sequences reveals a distinct spatial distribution of basic residues. J Biol Chem 268:19228-19231

Masuko S, Linhardt RJ (2012) Chemoenzymatic synthesis of the next generation of ultralow MW heparin therapeutics. Future Med Chem 4:289-296. https://doi.org/10.4155/fmc.11.185

McLean J (1959) The discovery of heparin. Circulation 19:75-78. https:// doi.org/10.1161/01.CIR.19.1.75

Miller-Andersson M, Borg H, Andersson L-O (1974) Purification of antithrombin III by affinity chromatography. Thromb Res 5:439-452. https://doi.org/10.1016/0049-3848(74)90001-2

Mosier PD, Krishnasamy C, Kellogg GE, Desai UR (2012) On the specificity of heparin/heparan sulfate binding to proteins. Anion-binding sites on antithrombin and thrombin are fundamentally different. PLoS One 7:1-12. https://doi.org/10.1371/journal.pone.0048632

Mulloy B, Linhardt RJ (2001) Order out of complexity-protein structures that interact with heparin. Curr Opin Struct Biol 11:623-628. https://doi.org/10.1016/S0959-440X(00)00257-8

Mulloy B, Forster MJ, Jones C, Davies DB (1993) N.M.R. and molecular-modelling studies of the solution conformation of heparin. Biochem J 293:849-858

Muñoz EM, Linhardt RJ (2004) Heparin-binding domains in vascular biology. Arterioscler Thromb Vasc Biol 24:1549-1557. https://doi. org/10.1161/01.ATV.0000137189.22999.3f

Nordenman B, Björk I (1977) Purification of thrombin by affinity chromatography on immobilized heparin. Thromb Res 11:799-808. https://doi.org/10.1016/0049-3848(77)90108-6

Olivecrona T, Egelrud T, Iverius P-H, Lindahl U (1971) Evidence for an ionic binding of lipoprotein lipase to heparin. Biochem Biophys Res Commun 43:524-529. https://doi.org/10.1016/0006-291X(71) 90645-0

Ori A, Wilkinson MC, Fernig DG (2011) A systems biology approach for the investigation of the heparin/heparan sulfate interactome. J Biol Chem 286:19892-19904. https://doi.org/10.1074/jbc.M111.228114 
Ornitz DM, Herr AB, Nilsson M, Westman J, Svahn CM, Waksman G (1995) FGF binding and FGF receptor activation by synthetic heparan-derived di- and trisaccharides. Science 268:432-436

Park TJ, Lee MY, Dordick JS, Linhardt RJ (2008) Signal amplification of target protein on heparin glycan microarray. Anal Biochem 383: 116-121. https://doi.org/10.1016/j.ab.2008.07.037

Pellegrini L, Burke DF, von Delft F, Mulloy B, Blundell TL (2000) Crystal structure of fibroblast growth factor receptor ectodomain bound to ligand and heparin. Nature 407:1029-1034. https://doi. org/10.1038/35039551

Perderiset M, Courty J, Mereau A, Chevet E, Barritault D (1992) Purification of a heparin binding FGF receptor (HB-FGFR) from adult bovine brain membranes. Biochimie 74:1091-1096. https:// doi.org/10.1016/0300-9084(92)90007-2

Perlin A, Mazurek M (1968) A proton magnetic resonance spectral study of heparin.: L-Iduronic acid residues in commercial heparins. Carbohydr Res 5:369-379. https://doi.org/10.1016/S00086215(00)81210-0

Petitou M, Van Boeckel CAA (2004) A synthetic antithrombin III binding pentasaccharide is now a drug! What comes next? Angew Chemie Int Ed 43:3118-3133. https://doi.org/10.1002/anie.200300640

Pizarro SA, Gunson J, Field MJ, Dinges R, Khoo S, Dalal M, Lee M, Kaleas KA, Moiseff K, Garnick S, Reilly DE, Laird MW, Schmelzer CH (2010) High-yield expression of human vascular endothelial growth factor VEGF 165 in Escherichia coli and purification for therapeutic applications. Protein Expr Purif 72:184-193. https:// doi.org/10.1016/j.pep.2010.03.007

Pulido D, Rebollido-Rios R, Valle J, Andreu D, Boix E, Torrent M (2017) Structural similarities in the CPC clip motif explain peptide-binding promiscuity between glycosaminoglycans and lipopolysaccharides. J R Soc Interface 14:20170423. https://doi.org/10.1098/rsif.2017.0423

Quaas B, Burmeister L, Li Z, Nimtz M, Hoffmann A, Rinas U (2018) Properties of dimeric, disulfide-linked rhBMP-2 recovered from $E$. coli derived inclusion bodies by mild extraction or chaotropic solubilization and subsequent refolding. Process Biochem 67:80-87. https://doi.org/10.1016/j.procbio.2018.02.001

Rane AM, Jonnalagadda S, Li Z (2013) On-column refolding of bone morphogenetic protein-2 using cation exchange resin. Protein Expr Purif 90:135-140. https://doi.org/10.1016/j.pep.2013.05.008

Riesenfeld J, Thunberg L, Hook M, Lindahl U (1981) The antithrombinbinding sequence of heparin. Location of essential N-sulfate groups. J Biol Chem 256:2389-2394

Robinson HC, Horner AA, Höök M, Ogren S, Lindahl U (1978) A proteoglycan form of heparin and its degradation to single-chain molecules. J Biol Chem 253:6687-6693

Robinson CJ, Mulloy B, Gallagher JT, Stringer SE (2006) VEGF165binding sites within heparan sulfate encompass two highly sulfated domains and can be liberated by K5 lyase. J Biol Chem 281:17311740. https://doi.org/10.1074/jbc.M510760200

Rosenberg RD (1978) Heparin, antithrombin, and abnormal clotting. Annu Rev Med 29:367-378. https://doi.org/10.1146/annurev.me. 29.020178 .002055

Ruppert R, Hoffmann E, Sebald W (1996) Human bone morphogenetic protein 2 contains a heparin-binding site which modifies its biological activity. Eur J Biochem 237:295-302. https://doi.org/10.1111/j. 1432-1033.1996.0295n.x

Schlessinger J, Plotnikov AN, Ibrahimi OA, Eliseenkova AV, Yeh BK, Yayon A, Linhardt RJ, Mohammadi M (2000) Crystal structure of a ternary FGF-FGFR-heparin complex reveals a dual role for heparin in FGFR binding and dimerization. Mol Cell 6:743-750. https://doi. org/10.1016/S1097-2765(00)00073-3

Seeger A, Rinas U (1996) Two-step chromatographic procedure for purification of basic fibroblast growth factor from recombinant Escherichia coli and characterization of the equilibrium parameters of adsorption. J Chromatogr A 746:17-24. https://doi.org/10.1016/ 0021-9673(96)00286-5
Sharapova NE, Kotnova AP, Galushkina ZM, Lavrova NV, Poletaeva NN, Tukhvatulin AE, Semikhin AS, Gromov AV, Soboleva LA, Ershova AS, Zaitsev VV, Sergienko OV, Lunin VG, Karyagina AS (2010) Production of the recombinant human bone morphogenetic protein-2 in Escherichia coli and testing of its biological activity in vitro and in vivo. Mol Biol 44:923-930. https://doi.org/10.1134/ S0026893310060099

Sheehan JP, Sadler JE (1994) Molecular mapping of the heparin-binding exosite of thrombin (antithrombin III/serine proteases). Biochemistry 91:5518-5522. https://doi.org/10.1073/pnas.91.12. 5518

Shelburne FA, Quarfordt FA, Quarford SH (1977) The interaction of heparin with an apoprotein of human very low density lipoprotein. J Clin Invest 60:944-950. https://doi.org/10.1172/JCI108849

Sobel M, Soler DF, Kermode JC, Harris RB (1992) Localization and characterization of a heparin binding domain peptide of human von Willebrand factor. J Biol Chem 267:8857-8862

Staby A, Sand MB, Hansen RG, Jacobsen JH, Andersen LA, Gerstenberg M, Bruus UK, Jensen IH (2005) Comparison of chromatographic ion-exchange resins: IV. Strong and weak cation-exchange resins and heparin resins. J Chromatogr A 1069:65-77. https://doi.org/ 10.1016/j.chroma.2004.11.094

Sugahara K, Kitagawa H (2002) Heparin and heparan sulfate biosynthesis. IUBMB Life (International Union Biochem Mol Biol Life) 54: 163-175. https://doi.org/10.1080/15216540214928

Thompson LD, Pantoliano MW, Springer BA (1994) Energetic characterization of the basic fibroblast growth factor-heparin interaction: identification of the heparin binding domain. Biochemistry 33: 3831-3840. https://doi.org/10.1021/bi00179a006

Torrent M, Nogués MV, Andreu D, Boix E (2012) The "CPC clip motif": a conserved structural signature for heparin-binding proteins. PLoS One 7:e42692. https://doi.org/10.1371/journal.pone.0042692

Tsiang M, Jain AK, Gibbs CS (1997) Functional requirements for inhibition of thrombin by antithrombin III in the presence and absence of heparin. J Biol Chem 272:12024-12029. https://doi.org/10.1074/ jbc.272.18.12024

Vallejo LF, Rinas U (2004) Optimized procedure for renaturation of recombinant human bone morphogenetic protein-2 at high protein concentration. Biotechnol Bioeng 85:601-609. https://doi.org/10. 1002/bit.10906

Volpi N, Maccari F, Suwan J, Linhardt RJ (2012) Electrophoresis for the analysis of heparin purity and quality. Electrophoresis 33:15311537. https://doi.org/10.1002/elps.201100479

Xiong S, Zhang L, He Q-Y (2008) Fractionation of proteins by heparin chromatography. Methods Mol Biol 424:213-221. https://doi.org/ 10.1007/978-1-60327-064-9 18

Xu D, Esko JD (2014) Demystifying heparan sulfate-protein interactions. Annu Rev Biochem 83:129-157. https://doi.org/10.1146/annurevbiochem-060713-035314

Xu X, Nagarajan H, Lewis NE, Pan S, Cai Z, Chen W, Xie M, Wang W, Hammond S, Mikael R, Neff N, Passarelli B, Koh W, Fan HC, Gui Y, Lee KH, Betenbaugh MJ, Quake SR (2012) The genomic sequence of the Chinese hamster ovary $(\mathrm{CHO}) \mathrm{K} 1$ cell line. Nat Biotechnol 29:735-741. https://doi.org/10.1038/nbt.1932.The

Ye S, Luo Y, Lu W, Jones RB, Linhardt RJ, Capila I, Toida T, Kan M, Pelletier H, McKeehan WL (2001) Structural basis for interaction of FGF-1, FGF-2, and FGF-7 with different heparan sulfate motifs. Biochemistry 40:14429-14439. https://doi.org/10.1021/bi011000u

Zhu X, Hsu BT, Rees DC (1993) Structural studies of the binding of the anti-ulcer drug sucrose octasulfate to acidic fibroblast growth factor. Structure 1:27-34. https://doi.org/10.1016/0969-2126(93)90006-3

Zulueta MML, Lin SY, Hu YP, Hung SC (2013) Synthetic heparin and heparan sulfate oligosaccharides and their protein interactions. Curr Opin Chem Biol 17:1023-1029. https://doi.org/10.1016/j.cbpa. 2013.10.008 